http://journal.uinsgd.ac.id/index.php/biodjati

\title{
Rafflesia zollingeriana Koord.: A REINSTATEMENT
}

\section{Dewi Lestari*1, Ridha Mahyuni ${ }^{2}$}

Received : August 10, 2021

Accepted : November 16, 2021

DOI: 10.15575/biodjati.v6i2.13597

${ }^{1}$ Research Centre for Plant Conservation and Botanical Garden BRIN LIPI, Purwodadi Botanic Garden, Jalan Raya Malang-Surabaya KM 65, Parerejo, Purwodadi, Pasuruan, Eat Java, Indonesia, 67163

${ }^{2}$ Herbarium Bogoriense, Botany Division Research Center for Biology BRIN LIPI, Cibinong Science Centre, Jalan Raya Jakarta Bogor KM 46,

Cibinong, West Java, Indonesia, 16911

e-mail:

*1dewi016@lipi.go.id

ridha.mahyuni@gmail.com

*Corresponding author
Abstract. Rafflesia zollingeriana Koord. was one of Rafflesia that distributed in Java. Although it has been stated as a different species, $R$. zollingeriana is sometimes still regarded as a synonym of $R$. patma. In addition, there are several contradictions in description of $R$. zollingeriana. Therefore, further investigation is needed. This study attempts presents a full the description of the R. zollingeriana female flower. In this study, a full description of female flower of $R$. zollingeriana and pictures of important characters such as ramenta, annulus, perigone lobes, disc, processes, bractea are presented. This study is also compared the morphology of $R$. zollingeriana and $R$. patma, to confirm their differences in size, opening of diaphragm, blotches and warts pattern on perigone lobes and diaphragm, annulus, and ramenta.

Keywords: East Java, Indonesia, morphology, Rafflesia, ramenta.

\section{Citation}

Lestari, D. \& Mahyuni, R. (2021). Rafflesia zollingeriana Koord.: A Reinstatement. Jurnal Biodjati, 6(2), 213-221.

\section{INTRODUCTION}

Indonesia has more than 15 species of Rafflesia distributed in Sumatra, Kalimantan, and Java. Three of them: Rafflesia patma Blume, Rafflesia rochussenii Teijsm. \& Binn. and Rafflesia zollingeriana Koorders, were distributed in Java (Nais, 2001). Rafflesia patma was first found by Deschamp from Nusa Kambangan island (van Steenis et al., 1954) and reported distributionin the southern coast of Java such as Leweung Sancang (Suwartini et al., 2008), Pangandaran, Bojonglarang (Ali et al., 2015), Leweung Cipeucang (Triana et al., 2017). R. rochussenii grows at 1246-1488 $\mathrm{m}$ asl such as Gunung Gede Pangrango National Park (Saadudin et al., 2012), but also can be found in $563 \mathrm{~m}$ asl. such as Mandapajaya, Kuningan (Supartono \& Herlina, 2018). R. zollingeriana Koord distributed in Meru Betiri National Park, East Java, and surrounding (Lestari et al., 2014a). This species was first described by Koorders from specimens found in Watangan Puger, Jember East Java. Recently, this species is reported rediscovered $5 \mathrm{~km}$ from Watangan Nature Reserve (BBKSDA, 2018).

$R$. rochussenii was different from $R$. patma and $R$. zollingeriana due to the absence of processes on the disk and the flat rim of 


\section{JURNAL BIDDJATI}

http://journal.uinsgd.ac.id/index.php/biodjati

the disk (Meijer, 1984). Koorders (1918) stated that $R$. zollingeriana was different from $R$. patma due to its smaller dimensions and the absence of the exterior annulus. But later, Meijer (1997) still considered $R$. zollingeriana as a synonym for $R$. patma though he also stated that $R$. zollingeriana was described by Koorders due to its smaller size and the ramenta that almost absent in the lower part of the flower tube. Meanwhile, Susatya (2011) described that the ramenta of $R$. zollingeriana spread evenly on the inner surface of the tube. He reaffirmed this in his last publication (Susatya et al., 2017). Further investigation is required to observe in-deepth and this study attempt to address it. There was no morphology evidence of female flower of $R$. zollingeriana, so this data is an addition and as morphological evidence that $R$ zollingeriana was different from $R$. patma. A full description of female flower with important characters such as ramenta, annulus, perigone lobes, disc, processes, bractea is presented.

\section{MATERIALS AND METHODS}

The study was conducted in Meru Betiri National Park, Jember, East Java in March 2016 with no specimen was taken. Morphological characterization was carried out directly in the field. Flower of $R$. zollingeriana was found at $180 \mathrm{~m}$ a.s.1. in Timunan Hill, Meru Betiri National Park. This hill is near to Wonoasri Village, Tempurejo, Jember, East Java. The parts observed including the diameter of flower, aperture, perigone lobes, diaphragm, ramenta, the disc, processi and annuli (Sofiyanti et al., 2007; Pranata et al., 2016). Those parts were measured by ruler and electronic digital caliper. The object was documented by two mirrorless cameras and dino-lite 3113 Series using some pieces of paper as a background. The morphological characters were compared with two flowers from the former study (2011-2012); a spirit specimen of $R$. zollingeriana in herbarium of Tabanan Hortus Botanicus Baliensis (THBB) and one herbarium of Pasuruan Hortus Botanicus Purwodadiensis (PHPB). The characters found compared with specimen of $R$. patma in Bojong Larang Nature Reserve, Cianjur, West Java (collected by Adlan Ali) to confirm their differences.

\section{RESULTS AND DISCUSSION}

\section{Description}

Rafflesia zollingeriana Koord., 1918, Bot. Overz. Rafflesiac. Need. Ind., 67, 1-128. -Type INDONESIA; Java, Puger, Koorders, $40312 \beta$ (holo, BO!)

Flower buds prior to bloom up to $23 \mathrm{~cm}$ in diameter (Figure 1). Mature female flower size $27 \times 25 \mathrm{~cm}$. Perigone lobes $5.9-10 \times 9$ $-12 \mathrm{~cm}$ with rounded apex. Warts have some irregular sizes. Perigone dominated by orange coloured background than white cream warts. Diaphragm $15 \times 17 \mathrm{~cm}$ in diameter, with irregular white cream warts more dominant than orange areas. Opening of diaphragm 8 $\times 9 \mathrm{~cm}$ in diameter. Flower tube $15 \mathrm{~cm}$ high. Ramenta below the surface of the diaphragm were groups of deeply or shallowly lobed tuberculate with $1.7-2.3 \mathrm{~mm}$ long. Disc 8.5 $\times 9 \mathrm{~cm}$ in diameter, rim disc $1.7 \mathrm{~cm}$ high with some smooth spines at the upper and lower rim, orange, surface of the disc white cream. Processes orange, spiky flat cone, arranged in three rings: 20 processes in the outer ring, 15 in the middle rings, and 10 in the central rings. Processes range from $0.5 \times 1.5 \mathrm{~cm}$ high, with some smooth spine at the top. Annulus covered with dense hairy; annulus exterior well developed, $8.2 \times 9.5 \mathrm{~cm}$ in diameter, thick $5 \mathrm{~mm}$; annulus interior $7.5 \times 9 \mathrm{~cm}$ in diameter, so thin, weakly developed, $1 \mathrm{~mm}$ 


\section{JURNAL BIDDJATI}

http://journal.uinsgd.ac.id/index.php/biodjati

thick. Central column $1.5 \mathrm{~cm}$ high, smooth groove running down to annulus interior with irregular size. Female flower with ovary in column, $6 \times 10 \mathrm{~cm}$ in diameter, $5.2 \mathrm{~cm}$ from the cupula (flower base). There are a lot of white tiny ovules in the chamber. Anthers are unknown.

\section{Spesimens Examined}

Indonesia: East Java, Meru Betiri National Park, 23 Desember 2016, DL 337 (THBB); Sukamade, Meru Betiri National Park, East Java, 27 June 1991, P1991060283 (PHBP).

\section{Phenology}

$R$. zollingeriana in this study blooms in March. In the previous study, Lestari et al. (2014b) found this species blooms during the

rainy or drain seasons: January, March, Aprit, June, July, August, October, and November.

\section{Distribution}

Meru Betiri National Park, Jember, Banyuwangi, East Java.

\section{Habitat}

$R$. zollingeriana growth on the hillside, on slightly acidic soil, lowland forest, slightly shaded area on $180 \mathrm{~m}$ asl.

\section{Conservation Status.}

The conservation status of $R$. zollingeriana, based on Lestari et al. (2014b) is vulnerable. Possible, that this status will be changed if there are the other information closed in this species

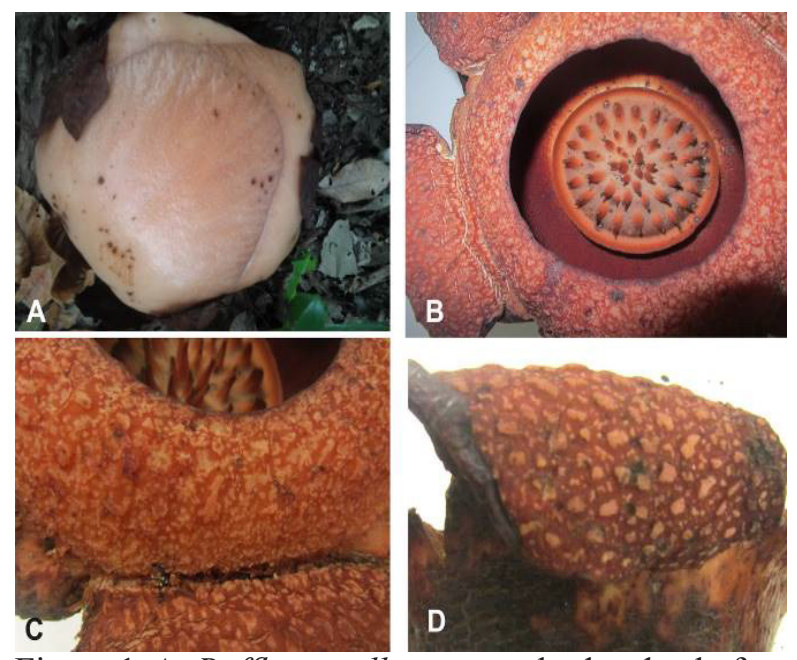

Figure 1. A. Rafflesia zollingeriana bud, a day before blooms. B. The opening diaphragm, C. Diaphragm that dominated by white cream warts, D. Warts of perigone dominated by orange background. (Photos: Dewi Lestari)

According to Koorders (1918) that $R$. zollingeriana develops with only inner annulus $\pm 4 \mathrm{~mm}$ wide ring, gradually sloping on both sides, in place of the outer annulus, but we found two annuli, interior, and exterior. Figures $4 \mathrm{~A}$ and $4 \mathrm{~B}$ showed that the exterior annulus is well developed into $5 \mathrm{~mm}$, while the interior annulus is weakly developed. Based on specimen of $R$. zollingeriana in THBB, it was seen so thin, shallowly wrinkled, almost fused with exterior annulus (Figure 5). Perhaps this very thin interior annulus made Susatya (2011) conclude that $R$. zollingeriana was only had one annulus.

For the character of ramenta, Koorders (1918) described that $R$. zollingeriana due 


\section{JURNAL BIODJATI}

http://journal.uinsgd.ac.id/index.php/biodjati

to its smaller size and the ramenta that are almost absent in the lower part of the flower tube. This study found that ramenta of $R$. zollingeriana spread evenly in the inner surface of diaphragm and inner of the tube, into $1-2 \mathrm{~cm}$ before exterior annulus (Figure 2C and 2F). It supported Susatya (2011) statement that ramenta spread evenly on the inner surface of the tube.
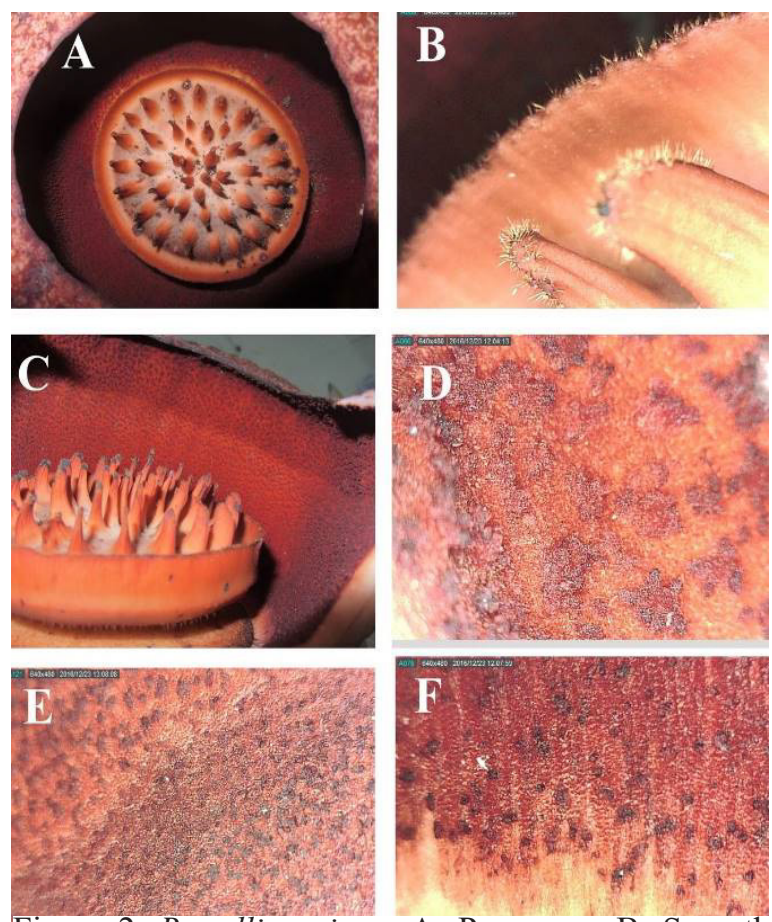

Figure 2. R. zollingeriana. A. Processes. B. Smooth spine on the top of processes and disc rim (upper and lower); C. The pattern of ramenta in the lower surface of diaphragm, in the middle of the tube and lower of the tube; D. Ramenta in the lower surface of diaphragm consist of groups of deeply or shallowly lobe tuberculate; E. Dense single tuberculate in the middle of the tube; F. Sparsely single tuberculate ramenta in lower tube. Ramenta in this section is shorter than ramenta in the middle of the tube. There is an empty zone without ramenta (about $0.8-1 \mathrm{~cm}$ ) between the last ramenta and annuli. This zone is indicated by white cream colour. (Photos: Dewi Lestari)

Lestari \& Mahyuni

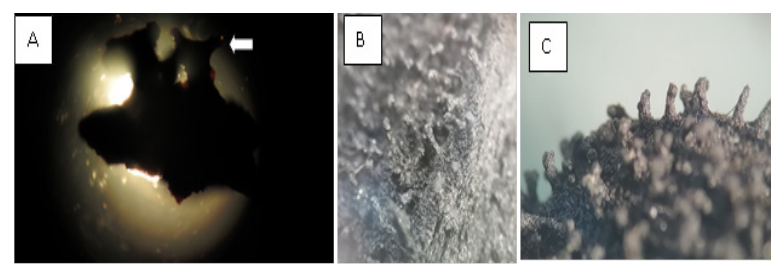

Figure 3. Ramenta of R. zollingeriana. A. Ramenta in the lower surface of diaphragm were groups of deeply or shallowly lobe tuberculate (arrow); B. Dense single tuberculate ramenta in the middle of the tube; $\mathrm{C}$. Shorter tuberculate ramenta before annuli. (Photos 4A: Dewi Lestari; Photo 4B, 4C: Aninda RUW)
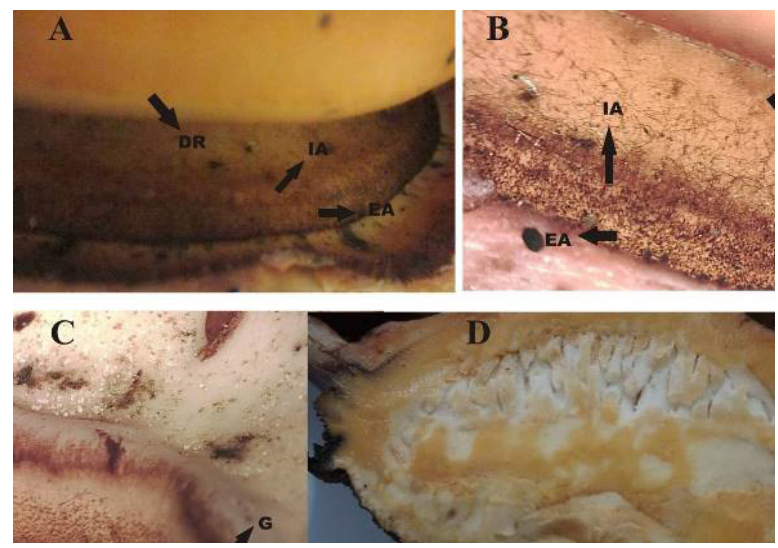

Figure 4. A. Disc, disc rim, and annulus in the base of the tube; B. Cilia fills area beyond the disc, especially in the annulus. Exterior annulus (EA) well developed, with $0.5 \mathrm{~cm}$ thick, interior annulus weakly developed, only $0.1 \mathrm{~cm}$ thick; C. Shallow groove (G) beneath the disc was without hairy ridges; D. Ovary in the column with a lot of white tiny ovules. (Photos: Dewi Lestari)
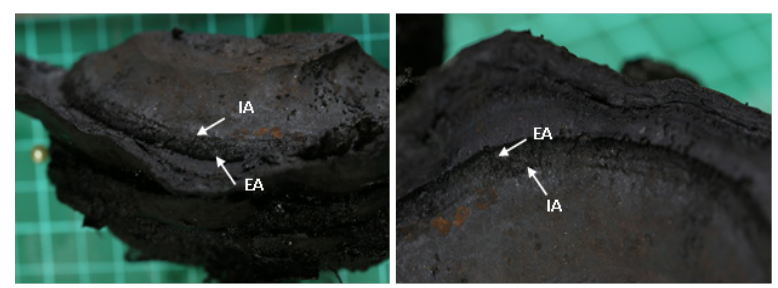

Figure 5. The interior annulus was so thin, fused to the exterior annulus. A. Annulus from a side view; $\mathrm{B}$. Annulus from the above view. (Photos of spirit specimen THBB: Aninda RU Wibowo). 


\section{JURNAL BIODJATI}

http://journal.uinsgd.ac.id/index.php/biodjati

\section{Differences of Rafflesia zollingeriana and Rafflesia patma}

Some characters like flower size, the diameter of the opening diaphragm, number of processes, the pattern of white blotches on the perigone lobes and diaphragm, structure and length of ramenta, and their position, number of annulus and column used to be compared.

The size of $R$. zollingeriana was $27 \mathrm{~cm}$ (Figure 6A) and R. patma size (Figure 6B) in Bojong Larang Nature Reserve was about 43 $\mathrm{cm}$. The other two flowers of $R$. zollingeriana that have been seen in Meru Betiri National Park were also about $30-32 \mathrm{~cm}$. Diameter of R. patma in Bogor Botanic Garden is also 40 $\mathrm{cm}$ (Mursidawati et al., 2020) and Hidayati et al. (2000) said that the diameter of R. patma fully flowers are $40-52 \mathrm{~cm}$. These confirmed that $R$. zollingeriana is smaller than $R$. patma.

Figure 6 showed that white cream

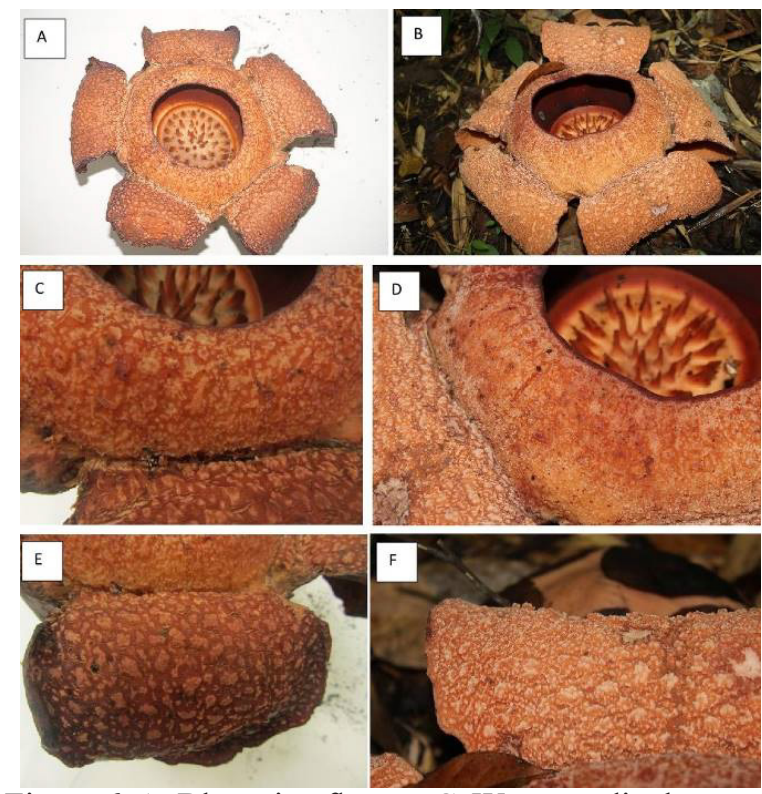

Figure 6. A. Blooming flower; C. Warts on diaphragm; E. Warts on perigone lobes (A, C \& $\mathrm{E} R$. zollingeriana in Meru Betiri National Park); B. Blooming Flowers; D. Warts on diaphragm; F. Warts on perigone lobes (B, $\mathrm{D}$, \& F $R$. patma in Bojong Larang Nature Reserve). (Photos of $R$. zollingeriana: Dewi Lestari; Photos of R. patma: M Adlan Ali)

Jurnal Biodjati 6(2):213-221, November 2021 blotches dominated in the perigone and diaphragm of $R$. patma, so its colour is lighter than $R$. zollingeriana. White cream blotches and warts in $R$. patma spread evenly and irregular pattern, white cream in perigone of $R$. zollingeriana spread in a regular pattern (Figure 1D). The pattern of warts on perigone is also differentiated $R$. hasseltii from $R$. cantleyi (Munirah et al., 2020).

Processes of $R$. zollingeriana is about 31 -33 , processes $R$ patma is $30-46$. The shape of both of them is similar. Processes in the middle of the disc are conical apex, processes at the edge are flattened apex (Figure 7). Processes colour are orange and the decaying processes is started by the darkening of the apex. The both of this species have three rings of processes, either in regular or irregular pattern (Figure 8).

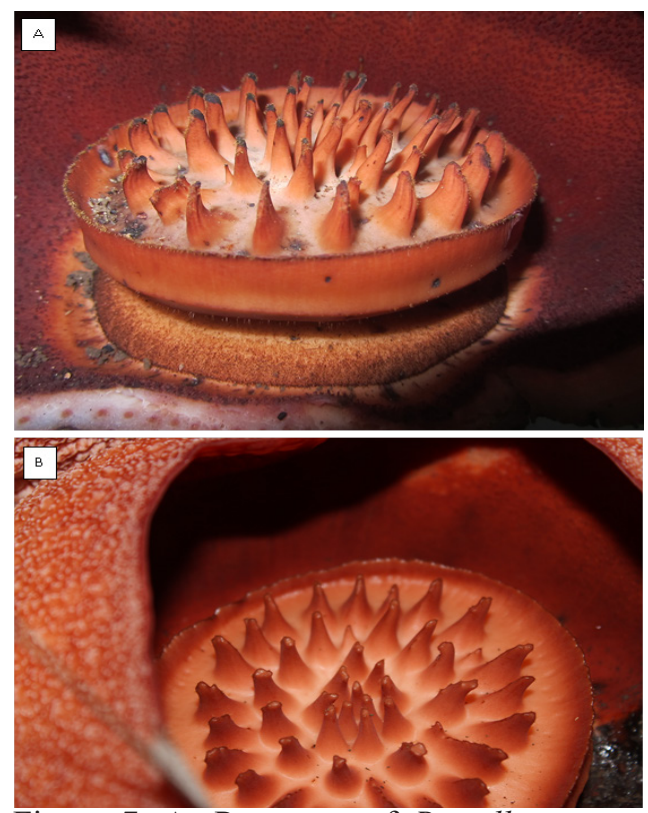

Figure 7. A. Processes of $R$. zollingeriana in Meru Betiri National park that start darkening its apex at $5^{\text {th }}$ day blooming; B. Processes of R. patma in Bojong Larang Nature Reserve at $2^{\text {nd }}$ day blooming. (Photo of $R$. zollingeriana: Dewi Lestari; Photo of R. patma: M Adlan Ali) 


\section{JURNAL BIODJATI}

http://journal.uinsgd.ac.id/index.php/biodjati
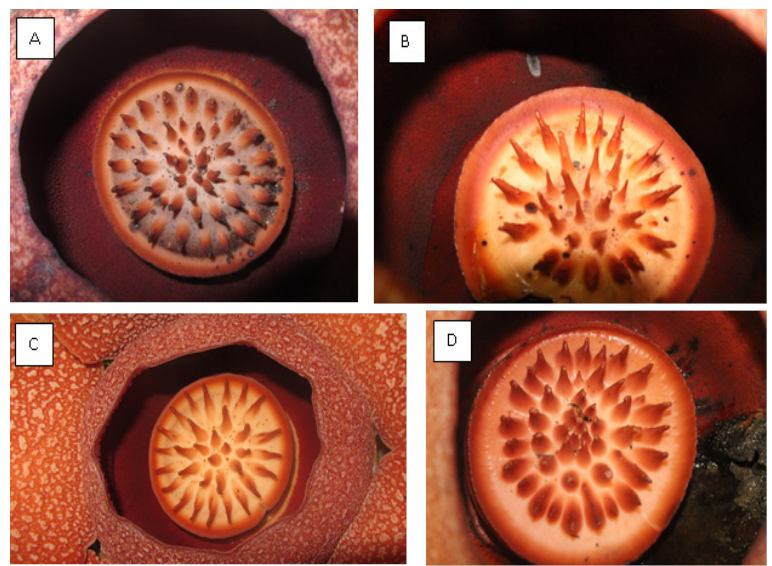

Figure 8 Processes (A, C) R. zollingeriana, R. patma $(\mathrm{B}, \mathrm{D})$ consist of three layers, either in regular or irregular pattern. (Photos of $R$. zollingeriana: Dewi Lestari; Photos of $R$. patma: M. Adlan Ali).

Ramenta is an important character in distinguishing species. Rafflesia patma and $R$. zollingeriana were categorized by Susatya et al. (2017) into a complex due to their ramenta characteristics. Both of them have simple tubercle ramenta, but different positions. The tuberculate ramenta of $R$. patma were only found at the inner surface of diaphragm (Figure 9D), but tubercle ramenta covered the inner diaphragm and the inner
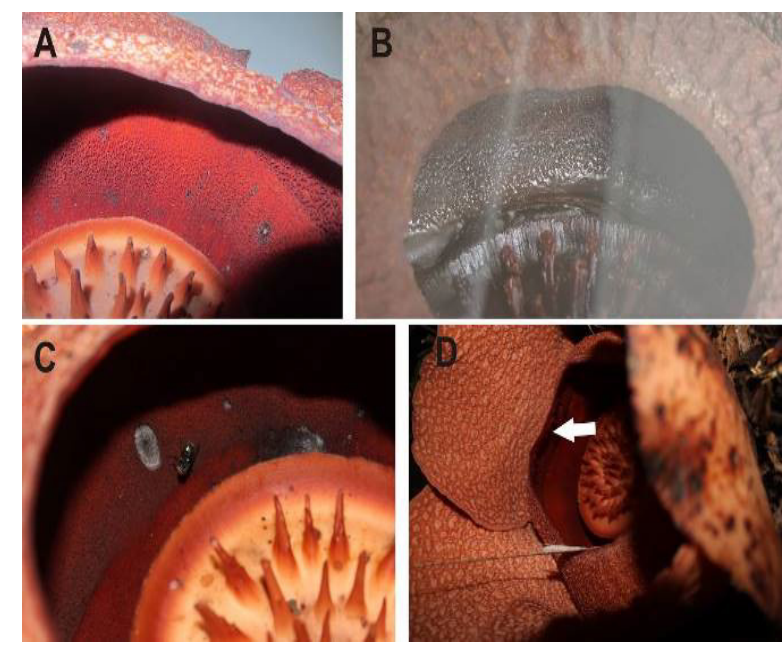

tube of $R$. zollingeriana, up to $1 \mathrm{~cm}$ before exterior annulus (Picture $2 \mathrm{C}$ and $2 \mathrm{~F}$ ). Instead of ramenta, the inner tube of $R$. patma was covered by tiny protuberances (Figure $9 \mathrm{C}$ ) or something that Mursidawati et al. (2020) called ramenta-like structures. Characters found to support Susatya (2011) who described that ramenta of $R$. zollingeriana spread evenly on the inner surface of the tube. Another evidence of ramenta in the lower tube of is also shown by in spirit specimen in PHBP (Figure 9B). Bendiksby et al. (2010), supported that both is a different clade. Morphology and molecular data support each other.

Meijer (1997) described that the annulus interior of $R$. patma was about 4-6 $\mathrm{mm}$ broad, well defined, and sharply elevated, about $8-9.5$ $\mathrm{cm}$ in diameter. Annulus exterior $3-10 \mathrm{~mm}$ wide average and c. $1 \mathrm{~mm}$ thick, rather weakly developed, wrinkled like a rolled-up blanket which is curved into a circle. Meanwhile, this study found that the annulus exterior of $R$. zollingeriana was well developed, $8.2 \times 9.5$ $\mathrm{cm}$ in diameter with thick $5 \mathrm{~mm}$, the annulus interior is weakly developed, $7.5 \times 9 \mathrm{~cm}$ in diameter, so thin, only $1 \mathrm{~mm}$ thick (Figure 4).

Figure 9. A. Ramenta in inner diaphragm and inner tube of $R$. zollingeriana; B. Ramenta also spread evenly in lower of the tube of $R$. zollingeriana, spirit collection of PHBP; C. There is no ramenta on the lower tube of $R$. patma, but the tube was filled with protrusion;.D. Tuberculate ramenta (arrow) were only in inner diaphragm of $R$. patma (Photo of $R$. zollingeriana: Dewi Lestari; Photos of R. patma: M. Adlan Ali) 


\section{JURNAL BIDDJATI}

http://journal.uinsgd.ac.id/index.php/biodjati

Table 1. Morphological comparison between Rafflesia zollingeriana and Rafflesia patma (Meijer 1997)

\begin{tabular}{|c|c|c|}
\hline Characteristics & R. zollingeriana & R. patma \\
\hline Flower size & $20-30 \mathrm{~cm}$ & $30-60 \mathrm{~cm}$ \\
\hline $\begin{array}{l}\text { Diameter of the opening } \\
\text { diaphragm }\end{array}$ & $8-9 \mathrm{~cm}$ & $5-9 \mathrm{~cm}$ \\
\hline Diameter of disc & $8-9 \mathrm{~cm}$ & (7) $9-13,5 \mathrm{~cm}$ \\
\hline Number of disc processes & $31-33$ & $30-46$ \\
\hline $\begin{array}{l}\text { White cream blotches on } \\
\text { the perigone lobes and } \\
\text { diaphragm }\end{array}$ & $\begin{array}{l}\text { creamy white warts in } \\
\text { perigone lobes arranged in a } \\
\text { regular shape, creamy white } \\
\text { warts in diaphragm arranged } \\
\text { in an irregular shape }\end{array}$ & $\begin{array}{l}\text { the irregular shape of creamy } \\
\text { white warts dominated the lobes } \\
\text { and diaphragm }\end{array}$ \\
\hline $\begin{array}{l}\text { Colour on diapraghm and } \\
\text { perigone lobes }\end{array}$ & $\begin{array}{l}\text { orange colour dominated } \\
\text { the perigone lobes }\end{array}$ & brighter than $R$. zollingeriana \\
\hline $\begin{array}{l}\text { Structure and length of } \\
\text { ramenta and position of their } \\
\text { occurrence }\end{array}$ & $\begin{array}{l}\text { simple tuberculate ramenta } \\
\text { scattered in the tube, from } \\
\text { lower of the diaphragm into } \\
1 \mathrm{~cm} \text { before annulus }\end{array}$ & $\begin{array}{l}\text { tuberculate ramenta only in the } \\
\text { lower of diaphragm }\end{array}$ \\
\hline Number of annulus & $\begin{array}{l}\text { 2, interior annulus less } \\
\text { developed than exterior } \\
\text { annulus }\end{array}$ & $\begin{array}{l}\text { 2, exterior annulus less developed } \\
\text { than interior annulus }\end{array}$ \\
\hline
\end{tabular}

\section{ACKNOWLEDGMENTS}

This study was carried out as a part of $R$. zollingeriana population dynamics research that conducted at Timunan Hill, Meru Betiri National Park in 2015-2016. Authors would like to thank to Meru Betiri National Park for permitting the research; Nanang Joko Rianto and Tohed for assistance in the site; Aninda RUW, Gusti Ngurah Sudirga, Made Suryani, Novita Mudji for assistance in THBB and PHBP. Our gratitude is also devoted for M.A. Ali which is his pictures used in this publication.

Dewi Lestari (DL) is major author of this manuscript and Ridha Mahyuni (RM) is co-author. DL design the study, collecting the data, analyzing the data and write the manuscript with support from RM. RM also contributed in data analyzing of $R$. zollingeriana specimens.

\section{REFERENCES}

Ali, M. A., Hikmat, A. \& Zuhud, E. A. M. (2015). Kajian Karakteristik Habitat Rafflesia (Rafflesia patma Blume.) di Cagar Alam Bojonglarang Jayanti, Cianjur, Jawa Barat. Media Konservasi, 20(1), 9-14.

BBKSDA. (2018). Bunga Rafflesia Ternyata Masih Ada di Puger. Retrivied from https://bbksdajatim.org/bungarafflesia-ternyata-masih-ada-dipuger.php.

Bendiksby, M., Schumacher, T., Gussarova, G., Nais, J., Mat-Salleh, K., Sofiyanti, N., Madulid, D., Smith, S. A., \& Barkman, T. (2010). Elucidating the Evolutionary History of the Southeast Asian, Holoparasitic, Giant-Flowered Rafflesiaceae: Pliocene Vicariance, Morphological Convergence and Character Displacement. Molecular 


\section{JURNAL BIDDJATI}

http://journal.uinsgd.ac.id/index.php/biodjati

Phylogenetics and Evolution, 57(2), 620-633.

Hidayati, S. N., Meijer, W., Baskin, J. M. \& Walck, J. L. (2000). A Contribution to the Life History of the Rare Indonesian Holoparasite Rafflesia patma (Rafflesiaceae). Biotropica, 32(3), 408.

Koorders, S. H. (1918). Botanisch Oversicht der Rafflesiaceae van NederlandschIndie. Batavia: G. Kolff \& Co.

Lestari, D., Hikmat, A. \& Zuhud, E. A. M. (2014a). Conservation Strategy of Rafflesia zollingeriana Koord in Meru Betiri National Park, East Java. Jurnal Manajemen Hutan Tropika (Journal of Tropical Forest Management), 20(1), 9-16.

Lestari, D., Hikmat, A. \& Zuhud, E. A. M. (2014b). Distribusi Baru dan Struktur Populasi Rafflesia zollingeriana Koord. di Taman Nasional Meru Betiri, Jawa Timur. Buletin Kebun Raya, 17(2), 1-5.

Meijer, W. (1984). New Species of Rafflesia (Rafflesiaceae). Blumea, 30(1), 209215.

Meijer, W. (1997). Rafflesiaceae. In Kalkman, C., Kirkup, D., Nooteboom, H., Stevens, P. \& Wilde, W. (Eds.), Flora Malesiana (I (13), pp. 1-42). Rijksherbarium/Hortus Botanicus.

Munirah, S. M. Y., Salamah, A. \& Razelan, M. S. (2020). On the morphological variation of Rafflesia cantleyi (Rafflesiaceae) on Pulau Tioman, Pahang, Peninsular Malaysia. Blumea: Journal of Plant Taxonomy and Plant Geography, 65(1), 75-82.

Mursidawati, S., Wicaksono, A., \& Teixeira da Silva, J. A. (2020). Rafflesia patma Blume Flower Organs: Histology of the Epidermis and Vascular Structures, and a Search for Stomata. Planta, 251(6), 1-10.

Nais, J. (2001). Rafflesia of The World. Sabah Parks in Association with Natural History Publications.

Pranata, S., Sofiyanti, N. \& Fitmawati. (2016). Karakterisasi Morfologi Rafflesia di Kawasan Suaka Margasatwa Bukit Rimbang Bukit Baling Kabupaten Kampar Provinsi Riau. Jurnal Riau Biologia, 1(2), 107-112.

Saadudin, A. M., Hikmat, A. \& Prasetyo, L. (2012). Pemetaan Kesesuaian Habitat Rafflesia rochussenii Teijsm. Et Binn. di Resort Tapos Taman Nasional Gunung Gede Pangrango. Media Konservasi, 17(3), 154-161.

Sofiyanti, N., Matt-Saleh, K., Purwanto, D. \& Syahputra, E. (2007). The Note on Morphology of Rafflesia hasseltii Suringar from Bukit Tiga Puluh National Park, Riau. Biodiversitas, Journal of Biological Diversity, 8(4), 257-261.

Supartono, T. \& Herlina, N. (2018). Rafflesia and its Habitat Characteristics in Mandapajaya Forest, Kuningan District, West Java Province, Indonesia. Journal of Forestry and Environment, 01, 1-6.

Susatya, A. (2011). Rafflesia Pesona Bunga Terbesar di Dunia. Jakarta: Direktorat Kawasan Konservasi dan Bina Hutan Lindung.

Susatya, A., Hidayati, S. N., Mat-Salleh, K. \& Mahyuni, R. (2017). Ramenta Morphology and its Variations in Rafflesia (Rafflesiaceae). Flora, 230, 39-46.

Suwartini, R., Hikmat, A. \& Zuhud, E. A. M. (2008). Kondisi Vegetasi dan 
Jurnal Biodjati 6(2):213-221, November 2021

\section{JURNAL BIDDJATI}

http://journal.uinsgd.ac.id/index.php/biodjati

Populasi Rafflesia patma Blume di Cagar Alam Leuweung Sancang. Media Konservasi, 13(3), 1-8.

Triana, A. E., Hikmat, A. \& Basuni, S. (2017). Population of Rafflesia patma in Leuweung Cipeucang Geopark, Ciletuh, Sukabumi. Media Konservasi, 22(2), 196-204.
Van Steenis, C. G. G. J., van Steenis-Kruseman, M. J. \& Backer, C. A. (1954). Louis Auguste Deschamps. Bulletin of The British Museum (Natural History) Historical Series, 1(2), 49-68. 